\title{
Evaluation of Noise Level in selected Markets in Jos-North, Plateau State
}

\author{
Joshua YohannaGwanshak ${ }^{1 *}$, Onoja Sunday ${ }^{2}$, Jatau Ramond Yohanna $^{3}$ \\ ${ }^{1}$ Department of Geography, Plateau State University Bokkos, Plateau state Nigeria \\ ${ }^{2}$ National Centre for Remote Sensing, Jos, Plateau State, Nigeria. \\ ${ }^{3}$ Nigerian Correctional Service, Headquarter, Abuja, Nigeria
}

*Corresponding Authors: Joshua YohannaGwanshak, Department of Geography, Plateau State University Bokkos, Plateau state Nigeria

\begin{abstract}
Noise has been identified to be a silent killer yet, not much has been done to control its impact particularly in commercial centres of developing countries. this study evaluates and mapped noise level at notable commercial centres and selected markets in jos-north, plateau state with a view to underscore its existing harmful effects to the public.markets were purposively selected based on the intensity of relative activities observed at each point over time at locations such as, terminus, Gada-Biu and Katako market with a total of twenty-one (21) commercial (stalls) points using GPS coordinate points. Morning and evening records of noise level were recorded at the intervals of five (5) hours with sound level meter. The ArcGIS software was used for interpolation of the spatial distribution of noise level in selected study points at JosNorth as well as the equivalent noise level (leq). Noise level (db) for each stall was compared with permissive range provided by the regulatory body (NESREA), and it was observed that a majority of the points were above the stipulated standard of allowable noise level in human environment. Specifically, terminus market was within the range of $83.8 d b-90.4 d b$, Gada-Biu was $84.5 d b-91.1 d b$ while Katako market was within the range of 75.4db-100.9db. Highest peak of noise level in study was Katako market 98.5 db. Thus, implying high noise pollution generated from truck users and pushers activities at tuber food stalls, vehicular movement, cutting and milling machines and power generators. Thus suggested remedies to reduce the noise pollution were highlighted with a view to fight the health implications of high noise level among human beings patronizing such market on regular bases
\end{abstract}

Keywords: ArGIS, dB, Market, Jos-North, Noise Level Mapping, Noise Pollution, Sound Level Metres

\section{INTRODUCTION}

Noise is an unpleasant sound, being a product of urbanization and industrialization is now recognized as an emerged environmental nuisance (Nathaniel, 2007; Pathak, Tripathi and Mishra, 2008). Exposure to high levels of noise have differing effects within a given population, and the involvement of reactive oxygen species suggests possible avenues to treat or prevent damage to hearing and related cellular structures (Ingatius, 2016). Noise is an underestimated threat that can cause a number of short- and long-term health problems, such as sleep disturbance, cardiovascular effects, poorer work, poor school performance, hearing impairment, among others. Public complaint about excessive noise is more often in the recent times, most especially at market places.Markets are conjunction of buyers and vendors gather for their commercial, economic and social transactions that created communities and their activities as they gather, result in noise pollution of the environment. The numbers of purveyors and buyers to the tune of hundreds to thousands to people gathered and coupled with the fact that these markets are operated in open spaces create a serious environmental noise problem (Akpan, 2018). Some of the purveyors in an attempt to advertise their products thereby attracting customers shout and blare loudspeakers in full volume which result in indescribable noise pollution. Herbal medicine vendors are not excluded from this act, Small power generating sets are used by some vendors to run their grinding machines, source of power and these constitute serious noise hazard as the machines themselves also produce noise (Akpan, 2018). Pathways are created within the market space and there high vehicular movement of trucks, Lorries, cars, tricycles, and even 
motorcycles convey people, and goods into the market. It is again sources of noise within the entire market areas become much congested of human activities being carried out on both sides of the road that creates environmental population. Noise in market places have stemmed concerns towards human health particularly involving everyone engaging in commercial activities within market places and such noise produce commercial noise that have potential effects on the general public as a result of persistent exposure to excessive noise. This however, specks a concern to ascertain areas with high noise level of some selected markets places in Jos-north of Plateau state, Nigeria.

\section{LITERATURE REVIEW}

Noise is an intolerable level of sound that fuel annoyance, hampers mental and physical peace and may induce severe damage to the health (James 2016). According to Wawa and Mulaku (2015), noise is any sound that causes physiological uneasiness to the ear. People, especially those in urban communities, are exposed to noise without realizing its potential danger to their healthy hearing. Noise can cause irritation (Owojori 2017). Noise pollution as an unpleasant sound that is created by people or machines that can cause infuriation, distraction and physical pain on humans. Noise pollution can be generated from outdoor sources, such as road traffics, jet planes, garbage trucks, construction equipment, manufacturing processes, lawn mowers, leaf blowers, and indoor sources, including: boom boxes, heating and air conditioning units, and metal chairs scraping on doors (Akintunde, Bayei and Akintude, 2020).

Economical and social developments of people as well as various facets of human engagements are influenced by commercial activities of buying and selling. Nonetheless, developing countries have been linked with noise as environmental issues of commercial activities in market places (Ugbebor and Yorkor, 2015). Noise has potential affect on the general public with certain adverse effects to the health psychological and hearing loss. These health effects linked to noise pollution categorized into auditory and non-auditory effects (Mackenzie and David, 2008). Auditory noise effects consist of hearing impairment as well as effects such as noise induced hearing loss and presbycusis (Ugbebbor, 2017). The most acute and immediate effect of noise pollution is impairing of hearing which may cause auditory fatigue and may even finally lead to deafness. Auditory fatigue occurs when exposed to noise levels of $90 \mathrm{~dB}$ or above. In metro cities, most of the shopkeepers, cobblers, fruit sellers complain tinnitus in ear (Ignatius, 2016). Blasts and other intense or explosive sounds can rupture the eardrum or cause immediate damage to the structures of the middle and inner ear, while, hearing loss due to prolonged noise exposure is generally associated with destruction of the hair cells of the inner ear (Olaosun et al., 2009). On the other hand, Non-auditory effects of noise include cardiovascular disorder, hypertension, mental health, sleep disturbance, release of adrenaline, interference with speech communication, interference with learning process and annoyance (Ibekwe et al, 2016). Noise non-auditory effects are also alarming, because of the fact that they also cause severe diseases. It includes interference with speech communication, annoyance leading to illtemper, mental disturbance and violent behaviour (Ignatius, 2016).

Noise has been known to be a silent killer yet much has not been done to control it especially in developing countries like Nigeria (Kiernan, 1997). A spatial and temporal levels of noise pollution generated from urban traffic in Uyo metropolis, Nigeria and found that seven(7) out of eight (8) streets sampled for the study had noise levels exceeding the International Financial Agency and Environmental Protection Agency noise threshold of 55dB for residential and 70dB for industrial and commercial areas during weekdays and most weekends (Esinet al. 2017)

Noise mapping is a geographical representation of the sound level distribution existing in a given region. It is an efficient noise assessment method in urban areas. It also helped in visualization of the noise distributions in areas where land use are very sensitive to noise. This is one of the modern ways to assess noise levels and helps in planning to mitigate noise pollution effects (Oyedepo, 2013 and Panadya, 2013). The basic requirements for strategic noise mapping are an existing or a previous or a predicted noise situation, the exceeding of a limit, the estimated number of people location in an area exposed to certain levels of noise, estimated number of dwellings, schools and hospitals in a certain area exposed to specific values of noise indicator (Joshi, Joshi and Rane, 2015).Noise Mapping makes the government aware and hence enables them to take suitable measures in reducing it, thus leading to proper town planning and also control of people moving into designated noise environment. 


\section{MATERials AND Methods}

\subsection{Study Area}

Jos-North is situated at the northern edge of a pear-shaped upland known as the Jos Plateau, stretching for approximately $104 \mathrm{~km}$ from north to south and $80 \mathrm{~km}$ from east to west covering an area of $8,600 \mathrm{~km} 2$ or 806,000 hectares, and located between latitude $8^{0} 5^{0}$ to $9^{0} 47$ Being part of the Jos plateau, the study area is about $1120 \mathrm{~m}$ above mean sea level. The climate of the study area is characterized by two distinct seasons; wet season with mean rainfall of $1524 \mathrm{~mm}$ and average temperature of 20C. However, maximum temperature may reach $31^{\circ} \mathrm{Clow}$ as $11^{\circ} \mathrm{C}$ during the harmattan (Nigeria Metrological Synoptic Station (NIMET) Jos, Plateau). Jos-North is the capital of plateau state has the population of 650,839 by the 1991 population census, the 2006 national population census presented the figures to have increased to 821,618 (National Population Commission, Jos). Ccommercial activities which commenced in the early century brought an influx of expatriates and local labour from the surrounding areas into Jos metropolis. The economic base of Jos is predominantly dominated by commercial and public service employees. Another aspect of Jos Urban centre is the location of the market from which yields economic growth, the Terminus market was the biggest market in West Africa before it was burned while other shopping centres or corner shops exist within the neighbourhoods. This is an indication of high involvement of the populace in commercial ventures.

Markets were randomly and purposively selected with in Jos-north based on the major activities taking place at each point. Terminus market was the main market that deals with wholesales, GadaBiu market was a cluster roadside market while Katako market isaknown timber market with supporting commercial activities. Sound level measurements were carried out at seven (7) different locations in each of the markets with the sound level meter frequency evaluation filter (weighting|) set at $\mathrm{A}$ and at slow time evaluation because the noise generated was steady and had no sudden and rapid changes. The A filter was selected since it represents the characteristics curve of the human ear. Noise measurements were carried out twice day (morning and evening) at 0900GMT+1 to 1100GMT+1 and 1600GMT+1 to 1800GMT+1.

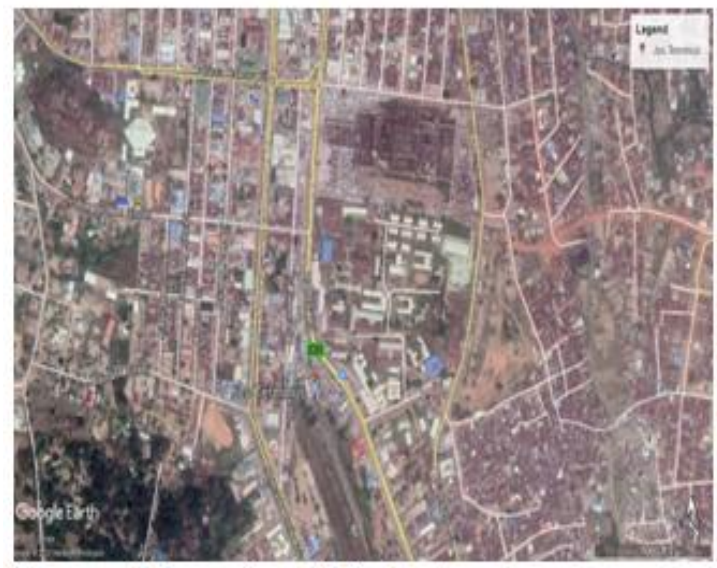

Figure 1Terminus Market

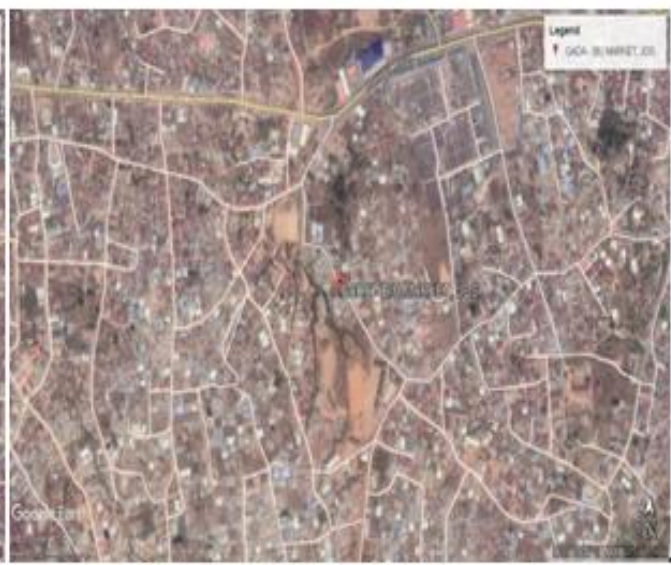

Figure 2.Gada-Biu

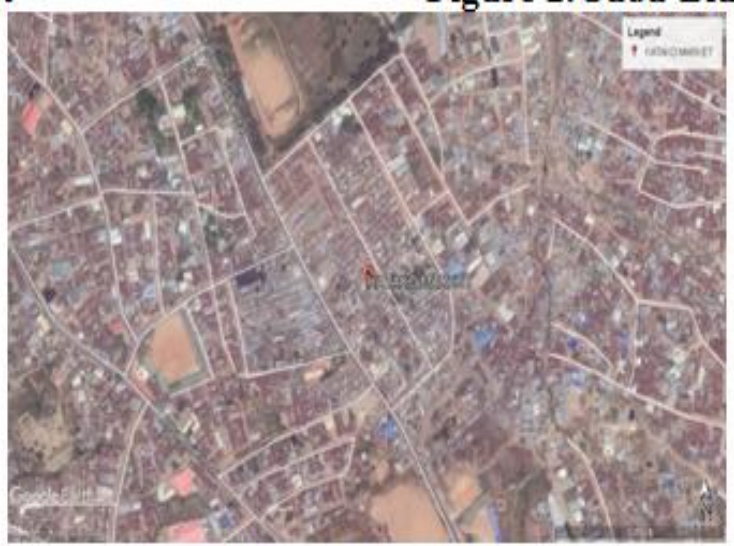

Figure3. Katako

Google Satellite Imagery of the selected Markets in Jos-North 
Table1. Selected Market, Location of Markets and Codes

\begin{tabular}{|l|l|l|}
\hline Market Name & Location Points & Code \\
\hline Terminus Market & Food tuber stall & TM1 \\
& Motor park & TM2 \\
& Scraps Materials stall & TM3 \\
& Vegetable oil Stall & TM4 \\
& Provision Stall & TM6 \\
& Pathways(vehicular movement \&Hawking) & TM7 \\
\hline Gada-Biu Market & Clothing and Shoes stall & GM1 \\
& Meup Condiments Stall & GM2 \\
& Plastic wares Stall & GM3 \\
& Milling Stall & GM4 \\
& Provision Stall & GM5 \\
& Bus stop (Road Side) & GM6 \\
& Gada-biu Motor Park & GM7 \\
\hline Katako Market & Palm oil Stall (Wholesale) & KM1 \\
& Wood Cutting Stall & KM2 \\
& Building Material stall & KM3 \\
& Kitchen Utensil Stall & KM4 \\
& Grains Stall & KM5 \\
& Major wood Milling Stall & KM6 \\
& Fairly-use Clothing Stall & KM7 \\
\hline
\end{tabular}

Fieldwork, 2020

Information was source from relevant literatures and journals on noise mapping within the study area as well as Jos-north Local Government Area secondary data collection involves sourcing information from existing records. Sound level Meter, GPS, ArcGIS, SPSS version 23.0 and Microsoft excel were instruments and software used for digitizing of noise thematic maps and analyzing the result.

\subsection{Measurement of Noise Level}

$$
\begin{aligned}
& \mathrm{L}_{\mathrm{eq}}(d B A)=10 \log _{10}\left[\left(\frac{1}{N}\right) \sum_{i=1}^{N} 10 \frac{L i}{10}\right] \ldots \ldots \ldots \ldots \ldots \ldots \ldots \mathrm{I} \\
& \mathrm{L}_{\mathrm{m}-\mathrm{e}}(d B A)=10 \log _{10}\left(\frac{1}{N}\right)\left[\mathrm{T} * 10\left(\frac{L 1}{10}\right)+\mathrm{T} * 10\left(\frac{L 2+10}{10}\right)\right] \ldots \ldots \ldots \ldots \ldots \mathrm{II} \\
& \text { Where }
\end{aligned}
$$

Where

- $\quad L_{\text {eq }}$ : Equivalent Sound Level

- $\quad L_{e q \_}, \mathrm{L}_{e q \_}$: Hourly A-weighted Equivalent Sound Level for the Morning and Evening Period.

- $L i$ : The Noise Level ith Reading

- $\quad N$ : Hour equivalent on a continuous basis

- $\quad L_{m_{-}}$: Equivalent Continuous Sound Level for Morning and Evening

4. ReSultS AND Discussions

In the research, the selected markets in Jos-North of Terminus, Gada-Biu and Katako were considered for the evaluation of noise level for urban control of the effect of noise to human health, each of the markets were marked on the bases of $\mathrm{dB}$ (decibel). Terminus market (TM) (see fig.1) in the morning hours recorded highest noise environment within the market to be tuber food stall (TM1) with an average of $88.8 \mathrm{~dB}$ and the lowest to recorded was $74.4 \mathrm{~dB}$ of pathways (TM6) with $74.4 \mathrm{~dB}$ while for evenings, provision stall was recorded with $89.7 \mathrm{~dB}$ as the highest noise environment and scrap material stall was recorded with lowest of $62.1 \mathrm{db}$. A daily total average of highest noise level was 85.9dB at MT5 with lowest at MT3 with $73.0 \mathrm{~dB}$. And the equivalent noise level (Leq) for terminus with the highest for the period of investigation was TM5 at $90.4 \mathrm{~dB}$. This by standard measurement of WHO and NESREA standard, terminus market stands above limits, it is considered to a noise environment.

Table2. Terminus Markets Average Noise Level for Morning, Evening and Leq

\begin{tabular}{|l|l|l|l|l|l|l|l|}
\hline Period & TM1 & TM2 & TM3 & TM4 & TM5 & TM6 & TM7 \\
\hline Morning & 88.8 & 83.7 & 83.8 & 85.3 & 82.0 & 74.4 & 83.1 \\
\hline Evening & 78.2 & 80.5 & 62.1 & 72.4 & 89.7 & 86.3 & 82.5 \\
\hline
\end{tabular}




\begin{tabular}{|l|l|l|l|l|l|l|l|}
\hline $\begin{array}{l}\text { Daily } \\
\text { Average(Lma) }\end{array}$ & 83.5 & 82.1 & 73.0 & 78.9 & 85.9 & 80.4 & 82.8 \\
\hline Leq & 90.2 & 85.4 & 83.8 & 85.5 & 90.4 & 86.6 & 85.8 \\
\hline
\end{tabular}

Table 3 shows Gada-Biu Market (see fig.2) recorded highest for morning period was market bus stop (GM7) with $90.5 \mathrm{~dB}$ and the lowest recorded noise level was Plastic ware Stall with $76.1 \mathrm{~dB}$ while at evening time, 86.5 was recorded at provision stall (GM5) as the highest and $63.3 \mathrm{~dB}$ at Plastic wares stall also. Highest average for Gada-Biu market was $86.8 \mathrm{~dB}$ at GM1 and lowest $69.7 \mathrm{~dB}$ at GM3. The records revealed above limits for the highest recorded in the morning records as well as highest evening but lowest for evening of GM3 and total lowest average were below WHO and NESREA standard with a records of $70 \mathrm{~dB}$ and $75 \mathrm{~dB}$ respectively. The equivalent noise level for Gada-Biu market at its highest peak was 91.1dB for two (2) locations GM5 and GM6 respectively

Table3. Gada-biu Average Noise Level for Morning, Evening and Led in Jos-North

\begin{tabular}{|l|l|l|l|l|l|l|l|}
\hline Period & GM1 & GM2 & GM3 & GM4 & GM5 & GM6 & GM7 \\
\hline Morning & 88.3 & 71.8 & 76.1 & 83.6 & 89.2 & 89.5 & 90.5 \\
\hline Evening & 85.2 & 84.3 & 63.3 & 80.1 & 86.5 & 74.2 & 82.1 \\
\hline Daily Average & 86.8 & 78.1 & 69.7 & 81.9 & 87.9 & 81.9 & 86.3 \\
\hline Leq & 90.0 & 84.5 & 84.9 & 85.2 & 91.1 & 89.6 & 91.1 \\
\hline
\end{tabular}

Katako Market (see fig.3) had morning apex record of $98.5 \mathrm{~dB}$ at Grains Stall (KM5) and base was at Palm oil stall (KM) with 75.2dB. For the evening record, $98.2 \mathrm{~dB}$ was the peak at major wood Milling stall (KM6) while the lowest was 61.8dB at Palm oil Stall (KM1) as revealed on table 4. The morning and evening noise level on daily total average revealed that 97.9dB at KM5 was highest for the daily average whereas $68.5 \mathrm{~dB}$ was the lowest recorded at KM1 for daily average. Thus, the equivalent noise level (Leg) for the period of one week at Katako market at its highest peak was $100.1 \mathrm{~dB}$ which is seen in the study as the highest recorded equivalent noise level. Katako Market have recorded noise level above standard limits for both WHO and NERSREA in morning records while the lowest for evening was below standard limit at KM1 as acceptable noise level.

Table4. Katako Average Noise Level for Morning, Evening and Led in Jos-North, Plateau

\begin{tabular}{|l|l|l|l|l|l|l|l|}
\hline Period & KM1 & KM2 & KM3 & KM4 & KM5 & KM6 & KM7 \\
\hline Morning & 75.2 & 83.2 & 84.3 & 76.2 & 98.5 & 95.0 & 84.3 \\
\hline Evening & 61.8 & 85.4 & 79.0 & 78.4 & 97.2 & 98.2 & 80.0 \\
\hline Daily Average & 68.5 & 84.3 & 81.7 & 77.3 & 97.9 & 96.6 & 82.2 \\
\hline Leq & 75.4 & 87.4 & 85.4 & 80.4 & 100.9 & 99.9 & 85.7 \\
\hline
\end{tabular}

Table5. Total Average Noise Level for the selected Markets in Jos-North, Plateau

\begin{tabular}{|l|l|l|l|l|l|l|l|}
\hline $\begin{array}{l}\text { Daily } \\
\text { Average }\end{array}$ & TM/GM/KT1 & TM/GM/KT2 & TM/GM/KT3 & TM/GM/KT4 & TM/GM/KT5 & TM/GM/KT6 & TM/GM/KT7 \\
\hline $\begin{array}{l}\text { Terminus } \\
\text { Market }\end{array}$ & 83.5 & 82.1 & 73.0 & 78.9 & $\mathbf{8 5 . 9}$ & $\mathbf{8 0 . 4}$ \\
\hline $\begin{array}{l}\text { Gada-biu } \\
\text { Market }\end{array}$ & 86.8 & 78.1 & 69.7 & 81.9 & 87.9 & 81.9 \\
\hline $\begin{array}{l}\text { Katako } \\
\text { Market }\end{array}$ & 68.5 & 84.3 & 81.7 & 77.3 & 97.9 & 96.6 & 86.3 \\
\hline $\begin{array}{l}\text { Total } \\
\text { Average }\end{array}$ & 79.6 & 81.5 & 74.8 & 79.4 & 90.6 & 86.3 & 83.8 \\
\hline
\end{tabular}

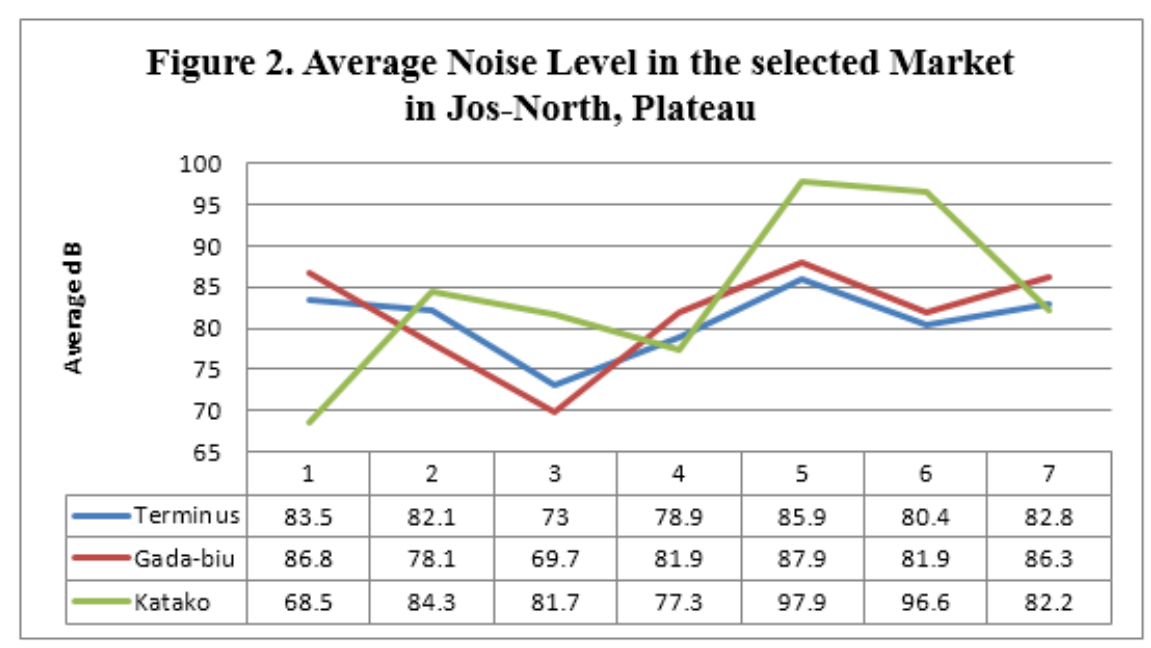


The interface noise level for the selected markets on the daily average shows (figure 2) that Katako market recorded noise among the selected markets at Point 2, 3, 5 and 6 with $84.3 \mathrm{~dB}, 81.7 \mathrm{~dB}, 97.9 \mathrm{~dB}$ and $96.6 \mathrm{~dB}$. Followed by Gada-Biu market at 1, 4, 56 and 7 with $86.8 \mathrm{~dB}, 81.9 \mathrm{~dB}, 87.9 \mathrm{~dB}, 81.9 \mathrm{~dB}$ and $86.3 \mathrm{~dB}$ while Terminus market had a daily average highest at point 2 and 3 with $82.1 \mathrm{~dB}$ and $73 \mathrm{~dB}$. However, lowest noise level point recorded on daily average was 68.5 at point 1 Katako market that was below standard limit.

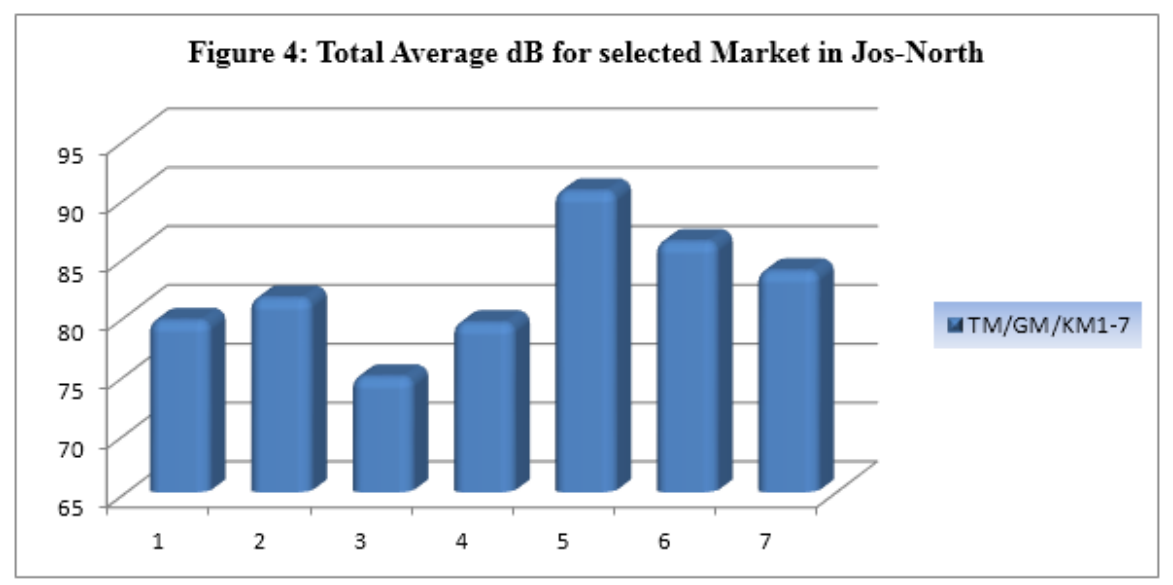

Figure 4 revealed the total average of noise level for selected markets in Jos-North, where point 5 was highest noise level on the study with $90.6 \mathrm{~dB}$ while point 3 was the lowest noise level with 74.8dB. This has shown that noise level in the selected markets depicts a high noise commercial markets that is considered as noise pollution. Jos-North of Plateau state is one of commercial centres in the northern with high patronage of goods and service.

The study revealed a high noise level in all the selected markets of Terminus, Gada-biu and Katako, it is this level, that Katako market was recorded most polluted noise commercial centre as a result of activities of high level trucks, milling and grinding. The wood milling stall attracts heavy duty trucks that supplies wood to the entire state and the processes of sizing the woods result to noise pollution. The standard noise level for commercial centre by the WHO and NESREA are $70 \mathrm{~dB}$ and $75 \mathrm{~dB}$ as against $90.6 \mathrm{~dB}$ of total daily average and $100.9 \mathrm{db}$ of (Leq) for the selected markets which have been translated into negative problem in the environment in the aspect of noise level. The noise level at commercial centre (Jos-north) was high due to activities that were misplacing distinctiveness in most of the markets.

Terminus market experience high noise pollution at the tuber food stall because trucks uploading and downloading of tubers of yam, Irish potatoes and others tubers, other activities of truck pushers conveying goods to customers. Vehicular movement at the bus stop at Gada-Biu contribute to a great extend the noisiest environment in the markets as result transporters activities on the roadside park with buyers and sellers. Noise experience at Katako market was rated highest among selected markets, most especially, the grain stall, major milling stall as well as building material stall. Noise level was attributed to pushing, dragging, cutting, milling, not only that but generators and machines operators added to it.

\section{Noise Mapping}

Noise mapping is a graphical representation of the sound level distribution existing in a given region; it is an efficient noise assessment method in urban areas. It also helps in visualization of the noise distribution in area where land uses are very sensitive to noise. This is one of the modern ways to assess noise levels and it helps in planning to mitigate noise pollution effects (Oyedepo et al, 2018; Oyedepo, 2013). In this study, build up noise map using GIS for the selected markets (Terminus, Gada- Biu and Katako Markets) in different stall within each of the market. Noise level (dB) were data collected from 21 stall locations used to developed a noise map for the study location in Josnorth. Figure 6 to 9 shows the satellite view of the study. ArcGIS 10.5 software was used in this study to develop noise map for terminus, Gada-Biu and Katako market. The software makes use of Inverse Distance Weighting (IDW) interpolation method. IDW provide satisfactory results when the number of elevation points in an area is large and points are uniformly distributed. Figure 4 for shows IDW for terminus morning with large cover 85-86 and only provision stall with 92-93 (dB). Fig 5 it is for 
evening at Terminus market cover large with $74-76(\mathrm{~dB})$ with the same provision stall have highest $\mathrm{dB}$. The large cover of noise level was the Soup condiments and provision stall while the highest noise level was Market Bus Stop in Gada-Biu Market for the morning hours. The evening hours map project the IDW of Gada-Biu market with Peak noise in Gada-Biu was provision stall and soup condiments. And for mapping Katako Market revealed the IDW for morning was grain stall while evening was fairly use clothing. The selected markets show a danger of noise pollution in the three markets in Jos-North.

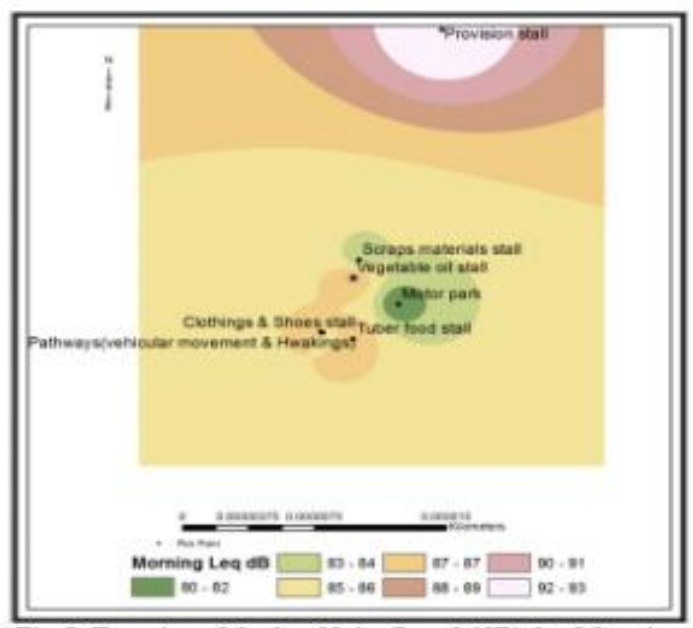

Fig 5. Terminus Market Noise Level (dB) for Morning

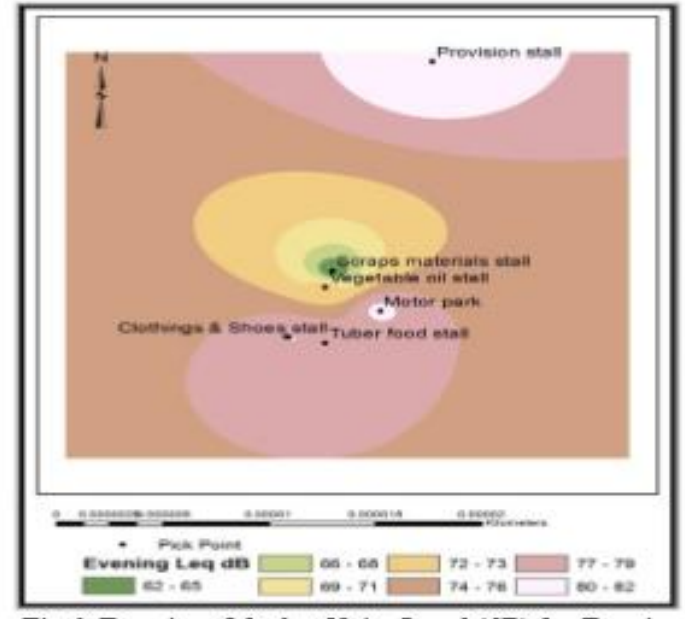

Fig 6. Terminus Market Noise Level (dB) for Evening
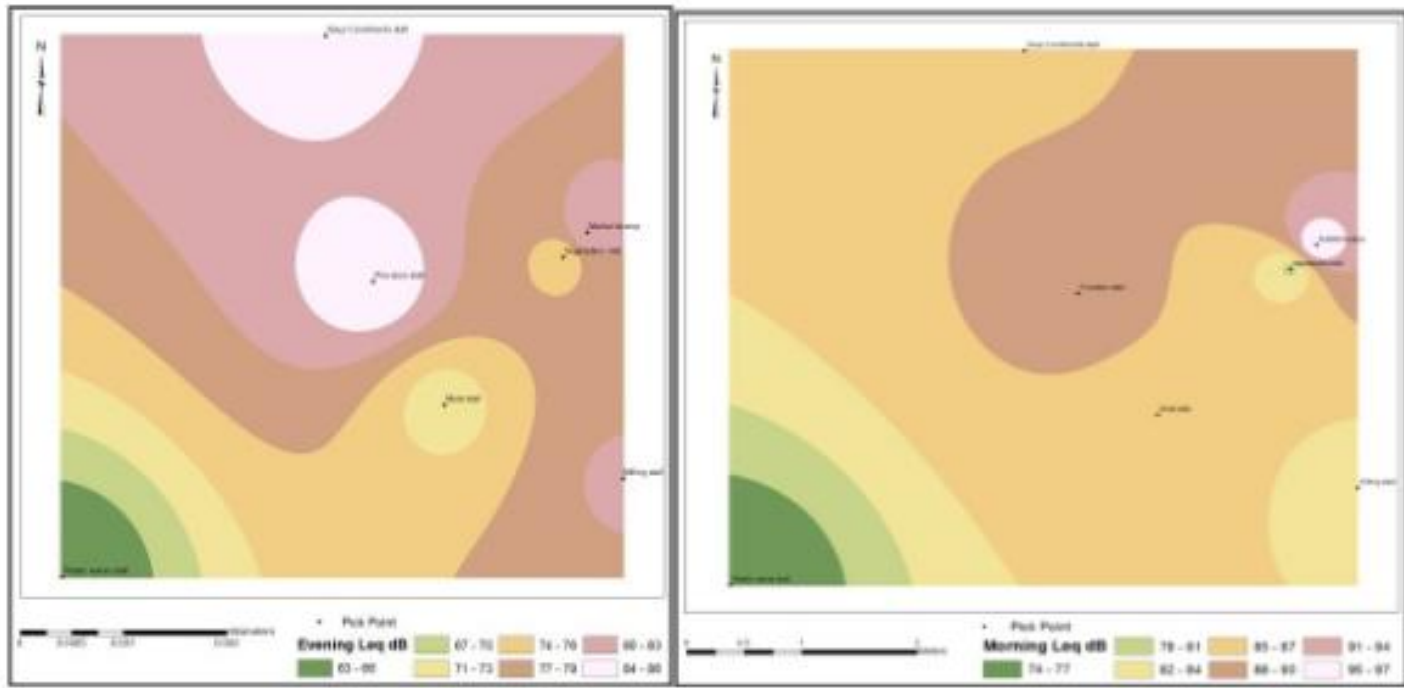

Fig 7 Gada-biu Market Noise Level (dB) for Morning

Fig 8 Gada-biu Market Noise Level (dB) for Evening

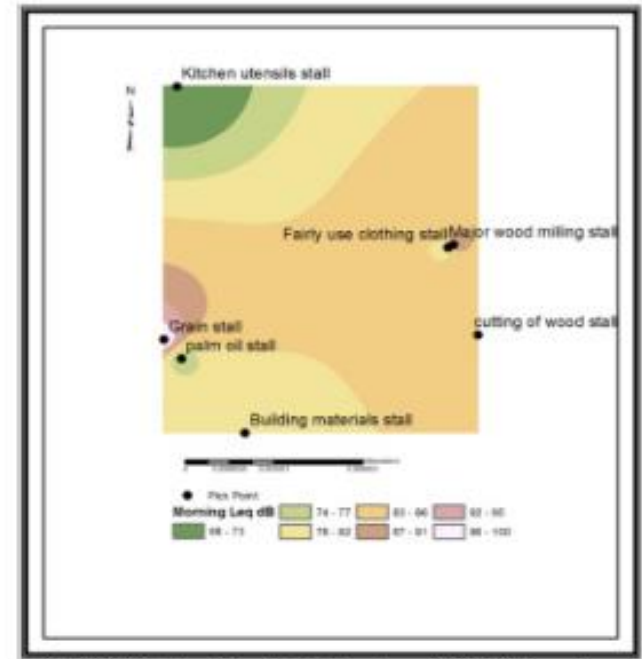

Fig 9. Katako Market Noise Level (dB) Morning

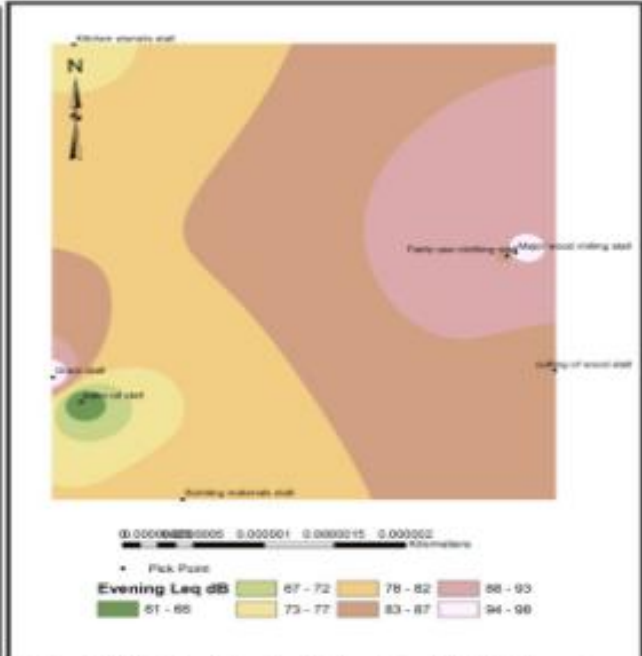

Fig 10. Katako Market Noise Level (dB) Evening 


\section{CONCLUSION}

Noise pollution in commercial centres of urban area is unavoidable and to a large extends difficult to control. Most especially in developing countries like Nigeria and Plateau to be precise. The study took records of noise level $(\mathrm{dB})$ in the morning hours and evening with the aim to investigate the level of noise pollution at market places. The result revealed that mornings period of terminus market $88.8 \mathrm{~dB}<89.7 \mathrm{~dB}$ evening period and Gada-Biu experienced also morning and evening noise level of $90.5 \mathrm{~dB}>86.8 \mathrm{~dB}$ while for Katako market experienced a morning record of $98.5 \mathrm{~dB}>98.2 \mathrm{~dB}$. By implication the markets in Jos-north of Plateau state is considered to be a noise market environment. The equivalent noise level (Leq) for the period of one week for Terminus Market was within the range of $83.8 \mathrm{~dB}-90.4 \mathrm{~dB}$, for Gada-Biu (Leq) was $84.5 \mathrm{~dB}-91.1 \mathrm{~dB}$ while Katako market for the period of one week had a range of $75.4 \mathrm{~dB}-100.9 \mathrm{~dB}$ which were above WHO and NESREA standard for noise level in commercial places. However, It is of necessity to provide remedy for high noise pollution experience in market place in Jos-North LGA of Plateau state to avoid unknowing reasons for noise pollution health challenges. Hence, this study has highlighted certain measures to put in place for remedy for noise level effects on human being.

- Use of loudspeakers for advertisement of products or goods should be discouraged at market places rather, create stall for every product, goods or service for customers to locate the stall.

- Markets should not be located close to the main road or major road in urban centres and a designed time frame for trucks movements within commercial centres should be implemented.

- Customers service areas should be sound proof receptions, especially, merchants that deals with equipments or machines that produces noise.

- State Ministry of Health, Federal Ministry of Health, Works Department and Market Associations should work together with Environmental Agency to set limitation for Noise levels at market places.

- Enlightenment of noise pollution effects on human beings should be promoted as well as encouraging individuals patronizing market places on regular bases should have a medical examination.

- National Orientation Agency (NOA) should educate Nigerians on noise level they receive, the harmful effect of noise pollution, effect on the health in the no distance time, implement a regular balance for checking noise barriers not to exceed the standard levels that will set by Government.

\section{REFERENCES}

[1] Akintunde, E. A., Bayei, J. Y. and Akintunde, J. A. (2020). Noise level mapping in University of Jos, Nigeria. GeoJournal. https://doi.org/10.1007/s10708-019-10135-w(0123456789().,-volV()0123456789().,volV)

[2] Akpan,A. O. (2018). Environmental Noise Pollution and Impact inMajor Markets of AkwaIbom State, Nigeria. Global Journal of Human Social Science (B), 18 (1);1- 6. Esinet al. 2017

[3] Ibekwe, T.S., Folorunsho, D.O., Dahilo, E.A., Gbujie, I.O.,Nwegbu, M.M., \&Nwaorgu, O.G. (2016). Evaluation ofmobile smartphones app as a screening tool for environmentalnoise monitoring. Journal of Occupational andEnvironmental Hygiene, 13(2), D31-D36.

[4] IgnatiusG. I. (2016). Evaluation of Noise Levels from Various Sources within Zaria Metropolis, Kaduna State, Nigeria. Department of Water Resources and Environmental Engineering, Faculty of Engineering, Ahmadu Bello University, Zaria, Nigeria.

[5] James, A. (2016). Assessment of noise pollution level at 5commercial area of Allahabad city, India. The Ecosean. AnInternational Quarterly Journal of Environmental Sciences.10(1\&2), 169-171.

[6] Joshi, A. N., Joshi, N. C., \& Rane, P. P.(2015). Noise Mappingin Mumbai city, India. International Journal of InnovativeScience, Engineering \& Technology, 2(3), 2348-7968.

[7] Kiernan, V. (1996): Noise pollution robs kidsoflanguage skills, New Scientist 48.

[8] Mackenzie, L. D. and David, A. C. (2008) Introduction toenvironmental engineering. McGraw HillCompanies, Inc; New York, 4th Ed; 2008.

[9] Nathaniel, M.M. (2007). Noise Pollution: the Sound behind Heart Effects. Environ Health Perspect; 115(11):A536-7. 
[10] Olaosun, A.O., Ogundiran, O. and Tobih, J.E. (2009). Health Hazards of Noise: A Review Article. Research Journal of Medical Sciences, 3(3), 115-122.

[11] Owojori, A.A. (2017). Assessment of noise level and its effectson teaching and learning process in primary and secondaryschools in Zaria Metropolis, Nigeria. M.Sc. Dissertation,Ahmadu Bello University.

[12] Oyedepo .S. O, Adeyemi, G.A., Fayomi O.S.I, Fagbemi, O.K, Solomon , R, Adekeye, T, Babalola, O.P, Akinyemi, Olawale, O.C, Joel, E.S, Nwanya, S>C, (2018) Dataset on noise level measurement in Ota metropolis, Nigeria, Data Brief. Doi:http://dx.doi.org/10.1016/j.jib.2018.12.049 (in press)

[13] Oyedepo, S.O. (2013). Development of noise map for Ilorin metropolis, Nigeria, Int. J. Environ. Stud. (2013) 1-13, doi:http://dx.doi. org/10.1080/00207233.2013.813716.

[14] Panadya,G.H.(2013) Assessment of traffic noise and its impact on community, Int. J. Environ. Stud. 60 (6) (2003) 595-602.

[15] Pathak, V. Tripathi, B.D and Mishra, V.K. (2008). Evaluation of Traffic Noise Pollution and Attitudes of Exposed Individuals in Working Place. Atmos Environ;42(16):3892-8. doi: 10.1016/j.atmosenv. 2007.12.070.

[16] Wawa, E. A., \&Mulaku, G. C. (2015). Noise Pollution mappingusing GIS in Nairobi, Kenya. Journal of GeographicInformation System, 7, 486-493. https://doi.org/10.4236/igis.2015.75039.

[17] Ugbebor, J. N.,Yorkor, B. and Nwogu, J. N. (2017).Evaluation of Noise Levels in Oil Mill Market and ItsEnvirons, Port Harcourt, Nigeria. British Journal of Applied Science \& Technology, 21(1): 1-11

[18] Ugbebor J. N., and Yorkor, B. (2015). Assessment andEvaluation of Noise Pollution levels inselected Sawmill Factories in PortHarcourt, Nigeria. International Journal onEmerging Technologies 6;

Citation: Joshua YohannaGwanshak, et.al., "Evaluation of Noise Level in selected Markets in Jos-North, Plateau State ", International Journal of Research in Environmental Science (IJRES), vol. 6, no. 3, pp. 27-35, 2020. Available: DOI: http://dx.doi.org/10.20431/2454-9444.0603003

Copyright: (C) 2020 Authors. This is an open-access article distributed under the terms of the Creative Commons Attribution License, which permits unrestricted use, distribution, and reproduction in any medium, provided the original author and source are credited. 